\title{
Prenatal Stress Caused by Movement Restriction Induces Changes in the Appendicular Osseous Development of CF-1 Mice Progeny
}

\author{
El Estrés Prenatal Causado por Restricción de Movimiento Induce Cambios en el Desarrollo Óseo \\ Apendicular de la Progenie de Ratones CF-1
}

"Pablo Lizana; *Ricardo Henríquez \& **Pablo Muñoz

LIZANA, P.; HENRÍQUEZ, R. \& MUÑOZ, P. Prenatal stress caused by movement restriction induces changes in the appendicular osseous development of CF-1 mice progeny. Int. J. Morphol., 30(3):1132-1138, 2012.

SUMMARY: Prenatal stress has been associated with alterations in weight and body size, as well as disturbances in the process of developing skeletal ossification, occurring during childbirth and the early stages of life. However, the effect evidence of prenatal stress on bone growth and development during the gestation period has been low; therefore, it is unknown whether these alterations are associated with potential for growth disorders Because of this, the study aims to determine the short-term effects of prenatal stress on the CF1 mouse bone structure growth in your date of birth. The female mice were divided randomly in two groups: controlled ( $\mathrm{n}=2$ ) and stressed $(n=3)$. The latter was put under stress by means of movement restriction during the last week of gestation. Second, an evaluation of their gestational development was made, obtaining measurements of their weight. Finally, diaphanization with $\mathrm{KOH}$ and staining with Alizarin red was used to measure the length of their appendicular bones and their flat pelvic bones, of 53 P0 mice ( 25 control; 28 stressed during gestation). The stressed mice's body weight $(\mathrm{p}=0.02)$ and the length of their appendicular bones (radii, $\mathrm{p}=0.0011 ; \mathrm{ulnae}, \mathrm{p}=$ 0.0001 ; humeri, $\mathrm{p}=0.0001$; femorae, $\mathrm{p}=0.0006$; tibiae, $\mathrm{p}=0.0015$ ) were affected significantly in contrast with the controlled group. On the other hand, there were no significant differences in maternal body weight and length of the mice pelvic bones (isquium, ilium; $\mathrm{p}>0.05$ ). The prenatal stress by means of movement restriction alters the osseous appendicular morphology of the CF-1 mouse evaluated at birth.

KEY WORDS: Prenatal Stress; CF1 Mouse; Alizarin red; Appendicular Skeletal; Morphometric, Movement restriction.

\section{INTRODUCTION}

The stress is an adaptative response present in all mammal scale, which allows the organism to confront physical or psichyc events that threaten the homeostasis of the internal medium (Chrousos \& Gold, 1992), generating two types of reaction: a fast one, which involves the adrenal sympathetic, and a slow one that activates the HypothalamusPituitary-adrenal axis (HPA axis). This axis functions by means of the secretion of the corticotropin-releasing hormone $(\mathrm{CRH})$, from the hypothalamus, stimulating the adenohypophysis to produce the adrenocorticotropin hormone $(\mathrm{ACTH})$, that induces the synthesis and secretion of the glucocorticoids (GCs) on the suprarenal cortex, cortisol in humans and corticosterone in rodents.

The GCs not only participate establishing the internal medium homeostasis but are also fundamental for several fetal organisms maturation, such as the osseous tissue (Sliwa et al., 2010). Various clinical evidences have proved that if the HPA axis activation is taken chronic, it loses its adaptation value, inducing the individual to undergo alterations of many sorts, from psychiatric (depression or anxiety conditions de Kloet et al., 2005) to cardiovascular and metabolic diseases (Barker, 1995). These malfunctions are closely related to variable degrees of the HPA axis deregulations and its associated neuronal circuits (Magariños et al., 1997; Cook \& Wellman, 2004; Radley et al., 2006), as well as the alterations presented in many organs, especially the osseous tissue, where mass loss and density decrease are caused (Miller et al., 1995; Ikeda et al., 2003).

During pregnancy, the activation of the maternal HPA axis and the resulting rise of the GCs levels as a response to the severe stress, does not significantly alter the level of fetal cortisol due to the action of the placental 11-b-

\footnotetext{
* Laboratorio de Antropología Física y Anatomía Humana, Laboratorio de Técnicas Anatómicas, Instituto de Biología, Facultad de Ciencias, Pontificia Universidad Católica de Valparaíso, Valparaíso, Chile.

** Centro Interdisciplinario de Neurociencia de Valparaíso, Universidad de Valparaíso, Valparaíso, Chile.
} 
hydroxysteroid dehydrogenase type 2 enzyme (11b-HSD2), which metabolizes it into cortisone with an $80 \%$ effectiveness (Weinstock, 2008). By contrast, the prolonged maternal HPA axis activation is produced under chronic stress conditions, generating hypercortisolemia, phenomenon which is associated with a disturbance in the 11b -HSD2 enzyme barrier function, exposing the fetus to high levels of GCs (Welberg et al., 2005; Mairesse et al., 2007). This abnormal rise of the GCs during gestation has been related to a weight and size of the breeding at birth (Welberg et al.). Furthermore, the activation of the maternal HPA axis comes with a sustained increase of plasmatic concentrations of catecholamines, which induce the vasoconstriction of the placental arteries, reducing the blood flow and the oxygen support to the fetus, events that might alter the fetal nutrition and activate the fetal HPA axis (Myers, 1975).

Likewise, it has been observed that the increase of the maternal GCs stimulates the production of placental CRH and the release of GCs from the fetus's adrenal glands, contributing to the establishment of a chronic fetal hypercortisolemia state (Buckingham, 2006). Such disorders might modify the function of the fetal neuroendocrine axis permanently (Owen et al., 2004), phenomenon that represents the so-called "Barker's fetal programming hypothesis" (Barker, 1995, 2004). This hypothesis establishes that several environmental factors, among which prenatal stress is found, acting in critical periods of growth may affect both maturation and organization of tissues and specific systems, generating lifelong changes (Seckl \& Holmes, 2007).

Among the systems that may be affected by prenatal stress is the skeletal system; within their functions are the charges support, the protection of various organs, ion storage and blood cells formation (Harris \& Heaney, 1969). The formation and growth of the osseous system begins at the early prenatal stages and are responsible for mainly two types of cells. The osteoblast, mononucleate cells, is responsible for the production of osseous extracellular matrix; and on the other hand, the osteoclast, uninucleate cells, the osseous matrix resorption for its remodeling (Raiz \& Kream, 1981; Buckwalter et al., 1995).

The formation and osseous growth processes may be influenced by physical factors, either nutritional or hormonal, at the prenatal stage (Lavine \& Grodzinsky, 1987; Brigton \& McCluskey, 1988). In this category, treatments with GCs during gestation can be remarked, which have been associated with a decrease of the fetal lineal growth (Holemans et al., 2003), a fetal osseous density decrease (Namgung \& Tsang, 2003) and a fetal osseous growth decrease (De Vos et al., 1995; Orzechowski et al., 2000). But it is unknown whether increased GCs intrinsically produced in chronic stress situations during pregnancy will produce alterations in linear bone growth of the offsprings.

\section{MATERIAL AND METHOD}

Animals and laboratory conditions. Mice from strain CF1 were used, females of 5 to 8 months of age and 2 breeding males from the biotery of the Pontificia Universidad Católica de Valparaíso Anatomic Techniques Laboratory (Chile), which were raised and treated under the procedures that follow the bioethical dimensions of management and care of the experimental species, in agreement with the policies of the Pontificia Universidad Católica de Valparaíso, Chile.

The rodent housed in Plexiglas jails, which were cleaned twice a week and kept under the standard conditions of the laboratory: reverse light-darkness cycle of 12 hours (light cycle, 20:00 to 8:00), temperature of $18 \pm 2{ }^{\circ} \mathrm{C}$, with water and food ad libitum (Sharp \& La Regina, 1998).

At the reach of a minimum weight of $30 \mathrm{~g}$, adult females were separated, mated with a breeding male for 5 to 7 days and weighed daily from the beginning of the mating process to determine the gestation moment. The females were divided in 2 groups: stressed mothers during gestation ( $\mathrm{Sm}$; $\mathrm{n}=3)$ and mother not submitted under stress protocol $(\mathrm{Cm}$; $\mathrm{n}=2$ ). Once the breeding were born, with no sex discrimination, each one was weighed to be sacrificed with diethyl ether steam.

Protocol of stress by movement restriction. Each of the pregnant females Sm group were subjected to stress protocol by restricting movement from the G15 day until the day before the birth of baby, keeping them in a opaque polyvinyl chloride tube (15 cm long x $4.5 \mathrm{~cm}$ in diameter) for 45 minutes, 3 times daily (09:00, 14:00, 18:00). Breeding females to achieve a minimum of 15 sessions of stress were considered for the study (Buynitsky \& Mostofsky, 2009). This protocol of stress, stated Gameiro et al. (2006), establishes an increased production of ACTH and GCs circulating in the pregnant females and Breeding. On the other hand, Carboni et al. (2010) using the same protocol states increased production of catecholamines in both breeding and pregnant females, so in this study based on the methodology of the cited studies and the results were not assessed the levels of cortisol and catecholamines during the process. $\mathrm{Cm}$ group females were handled only during cage cleaning (See figs.1A and 1B).

Diaphanization, staining and photography procedures. Once sacrificed, the breeding bodies were fixed in formalin 


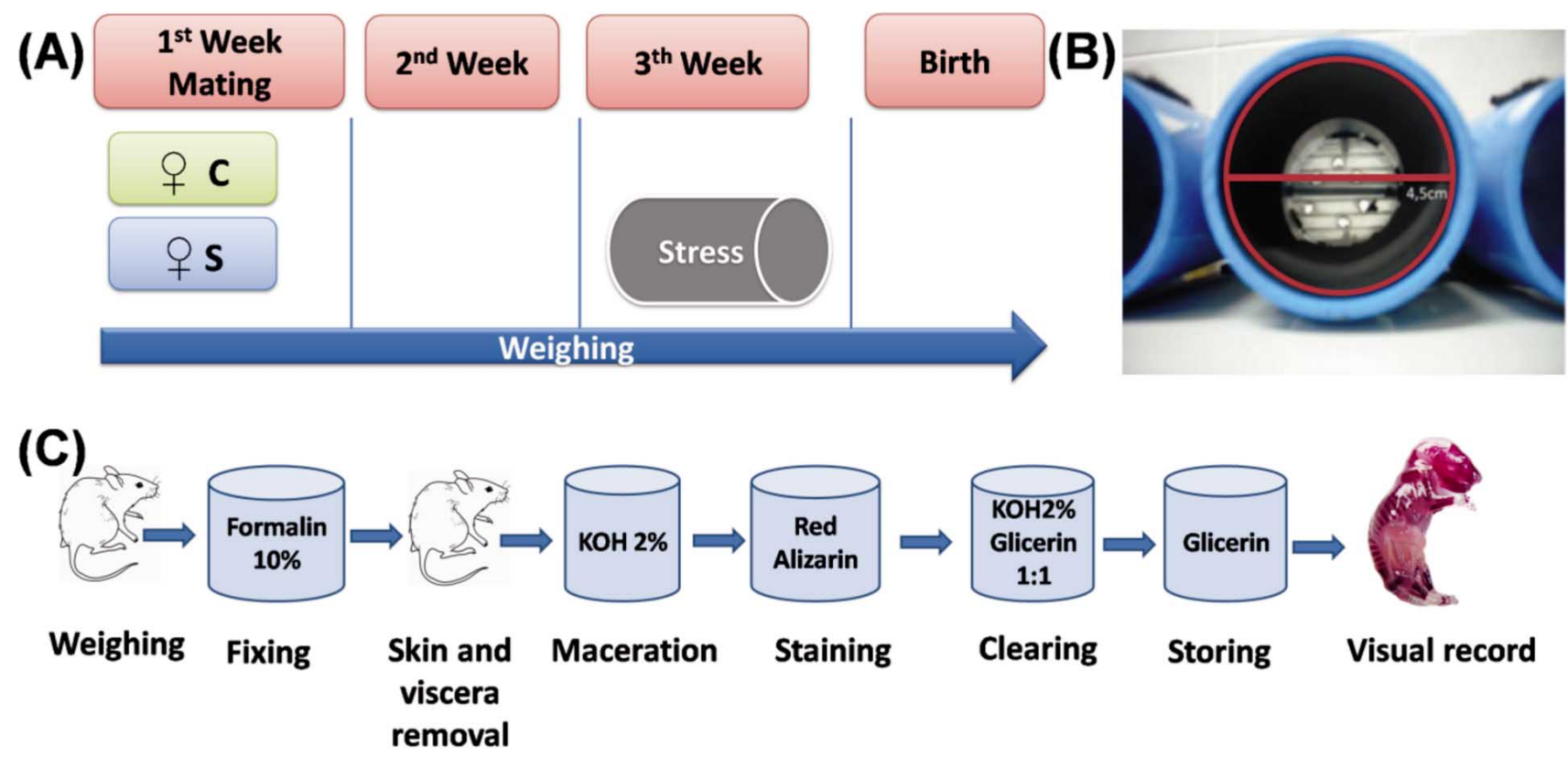

Fig. 1. Experimental design. (A) In the upper portion, the time since mating until the breeding birth of the controlled (c) and stressed (s) female groups is shown. The grey tube represents the stress moment and the arrow below the weighing throughout the whole process. (B) Photography of the tube in which pregnant females are submitted under stress by movement restriction. (C) Moment after birth since weighing, diaphanisation, staining, and photographic record. Following, the osseous morphometry is evaluated.

at $10 \%$ for one week to be later washed in tap water for an hour. At the end of this process, flaying, evisceration and extraction of the interscapular fat of the bodies were carried out, so as to be then subjected to maceration in potassium hydroxide $(\mathrm{KOH})$ at $2 \%$ for two weeks. For the staining process, red alizarin at $0.05 \%$ was used for two days, to finally immerse the corpse in a solution of $1: 1$ of $\mathrm{KOH} 2 \%$ and glycerin for a week to eliminate the remaining staining. The final samples were kept in glycerin for a minimum period of 3 days, to be photographed afterwards.

The process of photography was made with a Fujifilm FinePix HS10 camera, mounted on a tripod at $45 \mathrm{~cm}$ from the surface, under controlled illumination conditions. The corpses were placed on a surface with glycerin and contrasted with a measurement scale (see figure 1C).

Measuring procedure. The osseous lengths were analyzed with the Image Pro Plus program in its 6.0.0.260 version (Media Cybernetics, Silver Spring, USA®), evaluating the appendicular skeleton bone osseous lengths (humerus, ulna, femur and fibula-tibia complex) and the pelvic bone lengths in the coronal plane (ilium e isquium; figure $2 \mathrm{~A}$ and $2 \mathrm{~B}$ ). Both hemibodies were evaluated for the osseous measuring, averaging the values.
Statistical analysis. The data were processed by the MannWhitney's U test for unpaired, non-parametric data, considering the independent variable of prenatal stress. Among the dependent variables, the appendicular skeleton bone length and the pelvic bone length in the coronal plane were evaluated. A statistically significant result was considered $(\mathrm{p} \leq 0.05)$. The program STATA 9.2 was used to analyze the results.

\section{RESULTS}

No significant differences in body weight among the gestating mothers from the groups of study were found. The offspring of females subjected to stress during gestation (group $\mathrm{S} ; \mathrm{n}=28$ ) presented an average weight considerably lower than the ones whose mothers were not subjected to the protocol (group $\mathrm{C} ; \mathrm{n}=25)$ during the day $\mathrm{P} 0(\mathrm{p}=0.0034$; Fig. 2). An appreciably lower osseous length, compared to the ones in group $\mathrm{C}$ in the bones of appendicular skeleton under study, was presented by the group $\mathrm{S}$ breeding ( $\mathrm{p} \leq$ 0.05; Fig. 3C). However, the length in the coronal plane of the flat bones under study did not present significant differences. 


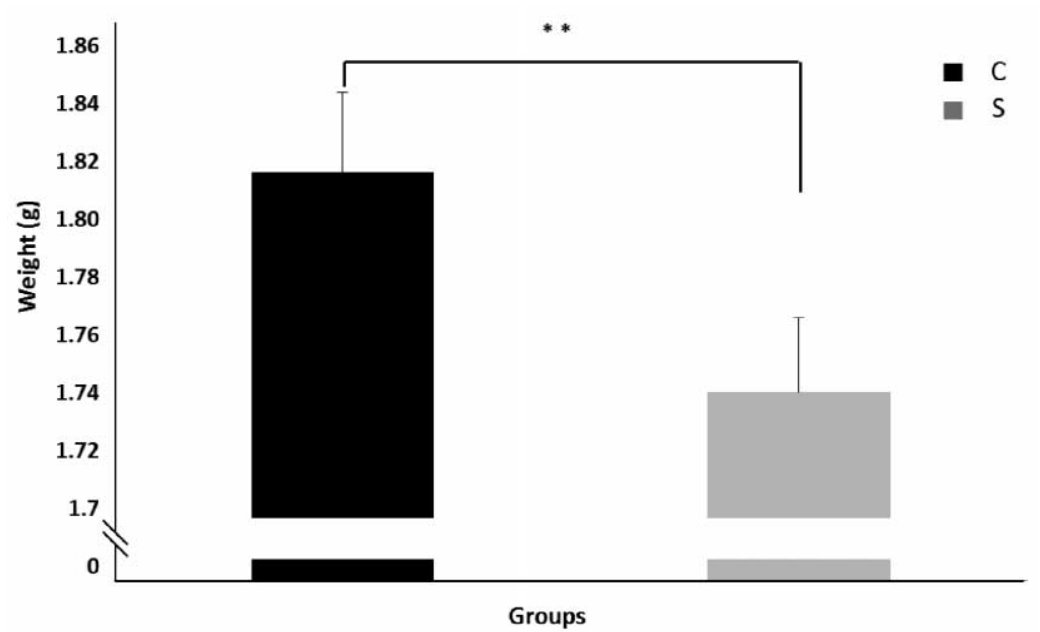

Fig. 2. Birth weight in mouse Cf1 control v/s experimental (stress; mothers subjected to immobilization during pregnancy). Average weight of each evaluated group in $\mathrm{P} 0 . \mathrm{C}=$ control group $(\mathrm{n}=25)$; $\mathrm{S}=$ group of breeding whose mothers were submitted under stress during gestation $(n=28)$. Data expressed as mean $\pm \mathrm{SE}(* *, \mathrm{p}<0.005)$.

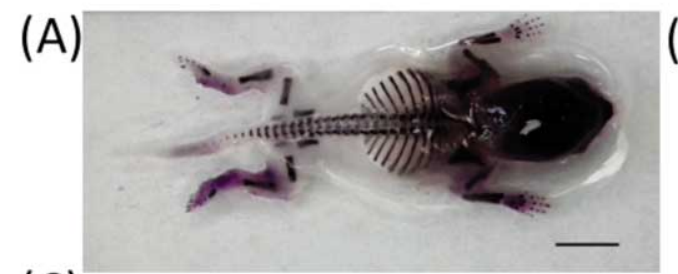

(B)

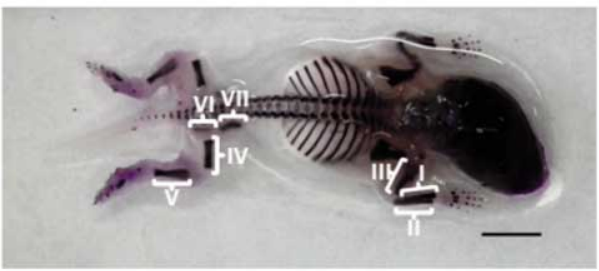

(C)

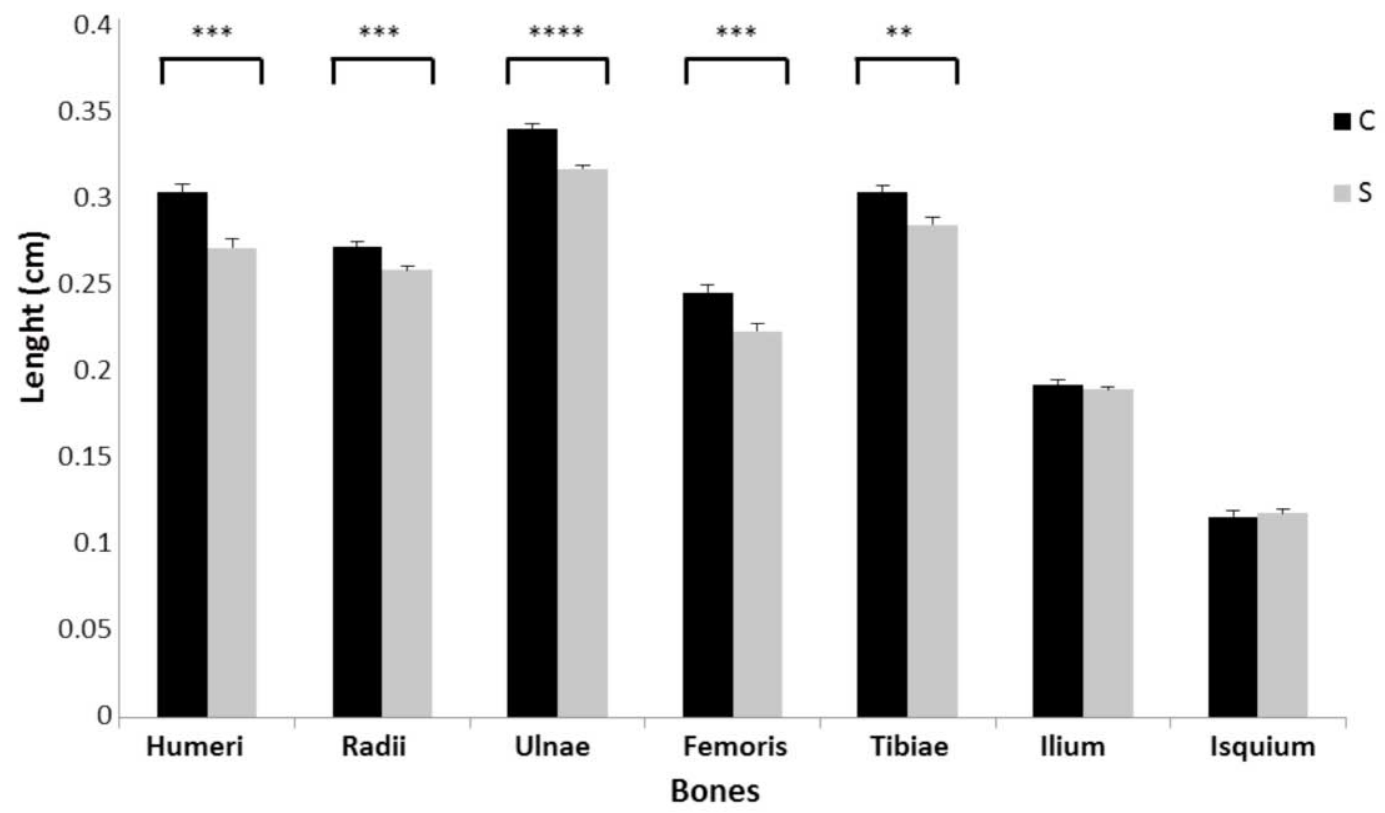

Fig. 3. Contrast between long bones of appendicular skeleton and flat pelvic bones in the coronal plane, after the gestational stress. Representative photographs of CF-1 mice after the staining process with red alizarin. (A) CF-1 mouse from the control group. (B) CF-1 mouse from the group stressed during gestation. The evaluated bones are shown: I) radii, II) ulnae, III) humeri, IV) femorae, V) tibiae, VI) isquium, VII) ilium. Scale bars indicate $0.5 \mathrm{~cm}$. (C) Average lengths of the stressed group $\mathrm{S}$ and the control group C. Bars indicates standard error. Differences between groups were evaluated through the U test by Mann-Whitney, Data expressed as mean $\pm \mathrm{SE}(*, \mathrm{p} \leq 0.05 ; * *, \mathrm{p} \leq 0.001 ; * * *, \mathrm{p} \leq 0.0001 ; * * * *, \mathrm{p} \leq 0.00001)$. 


\section{DISCUSSION}

The objective of this study was to analyze the short term effects of prenatal stress over the CF-1 mouse's osseous length. As regards the body weight of the breeding evaluated in $\mathrm{P} 0$, a considerably lower weight was presented by the $\mathrm{S}$ group compared to the control group, results that coincide with other studies (Lordi et al., 2000; Minagi et al., 2009); an evaluation of stressed female's breeding during the last trimester of gestation.

These results can be explained through two mechanisms that refer to the both GCs and catecholamine effect on the developing fetus. The first one describes the GCs as fosters in the increase of the circulating glucose, an alteration of the insulin receptors and a rise of the lipolysis, resulting in a lower weight at birth than the control animals (Ain et al., 2005). The second mechanism, mediated by catecholamines, is proposed by Lordi et al., who claims that a stressor agent will increase the plasmatic catecholamines, promoting a vasoconstriction of the umbilical vessels, diminishing the nutrient flow for the fetus, affecting its development and general growth.

When evaluating the appendicular skeleton long bone length of, a considerably greater one than the one of group $\mathrm{S}$ was found in the control group, which are similar results to the ones described by Sliwa et al. when studying the length of the humerus and femurs of suckling piglets in the postnatal day 30, compared to a control group and a bunch subjected to dexamethasone injections during gestation. Romano et al. (2009) describes similar results in the evaluation of femoral length of rats at 6 months of age, discovering that rodents subjected to a protocol of intrauterine prenatal growth restriction show a minor osseous length than the control group. Even Minangi et al. has described the possible presence of anatomical abnormalities / variations and osseous alterations in newborns.

These results can be explained by several mechanisms. The first of them refers to the GC effects over the cell lines in charge of the osseous growth and development, describing the increase of the apoptosis and the decrease in the proliferation of osteoblasts and osteocytes, as well as a raise in the osseous absorption and resorption of the osteoclasts (Hardy \& Cooper, 2009). Thus, the rises of the circulating GCs clearly boost an increase of the osseous resorption over formation, explaining to a certain extent the results observed in the osseous growth of long bones. The second mechanism could explain this event is related to the amount of the circulating catecholamines, which could produce umbilical vessel vasoconstriction (Lordi et al.), reducing the amount of nutrients and metabolites needed for the normal fetal development, generating alterations in the osseous growth and general development of the individual. Lastly, the third mechanism explaining the results obtained is based on the irrigation flow modification, as much towards the internal zones of the growing cartilage as the external ones, due to the circulating GCs (Weinstein $e t$ al., 2010), which could cause a reduction of the osseous formation in the growth cartilage that would affect directly the growth of the long bones of appendicular skeleton. An interesting result was that significant differences between groups $\mathrm{C}$ and $\mathrm{S}$ regarding the lengths of pelvic bones in coronal plane were not found. Two causes can explained this event: the first one is related to the possibility that the stress applied during the third trimester has not affected one of the periods with greater growth, since, according to Olsen et al. (2000) description, the pelvic bones have a intrauterine growth peak in the first two trimesters. Therefore, the stress applied in the study should not have affected the growth of these bones to a large extent; the second possible cause states that the pelvis and its constituent bones are flat, presenting two major dimensions rather than three, and as a result when measuring the length in the coronal plane only one of the dimensions was described, presenting, or not, differences of length in the horizontal plane. For further studies, the evaluation of the dimensions of the various corporeal planes would be interesting.

As a conclusion, drawn by the observations and results obtained, the chronic prenatal stress affects the osseous anatomy of CF1 mouse evaluated at birth, diminishing the osseous length of the long bones of appendicular skeleton, but with no variations in the coronal plane length of the pelvic bones.

\section{ACKNOWLEDGEMENTS}

The authors are very grateful to the Dirección de Investigación, Vice-rectoría de Investigación y Estudios Avanzados and the Instituto de Biología of the Facultad de Ciencias de la Pontificia Universidad Católica de Valparaíso, Chile, for their constant support.

LIZANA, P.; HENRÍQUEZ, R. \& MUÑOZ, P. El estrés prenatal causado por restricción de movimiento induce cambios en el desarrollo óseo apendicular de la progenie de ratonesCF-1. Int. J. Morphol., 30(3):1132-1138, 2012.

RESUMEN: El estrés prenatal se ha asociado con alteraciones en el peso y el tamaño corporal, así como trastornos en el 
proceso osificación en el esqueleto en desarrollo, que se producen durante el parto y las primeras etapas de vida. Sin embargo, la evidencia de los efectos del estrés prenatal sobre el crecimiento de los huesos y el desarrollo durante el período de gestación ha sido baja, desconociéndose si estas alteraciones están relacionadas con trastornos del crecimiento. El objetivo fue determinar los efectos a corto plazo del estrés prenatal en la estructura ósea del ratón CF-1 en el día de nacimiento. Las hembras gestantes fueron divididas aleatoriamente en dos grupos: control $(n=2)$ y estresado $(n=3)$. Este último fue puesto bajo estrés por restricción de movimiento durante la última semana de gestación. Evaluando el peso corporal en la progenie al nacer (grupo control $n=25$; grupo estresado $n=28$ ), para posteriormente diafanizar mediante $\mathrm{KOH}$ y teñir con alizarina roja, midiendo la longitud de huesos largos apendiculares y huesos planos de pelvis en el plano coronal. El peso de los ratones estresados $(\mathrm{p}=0,02)$ y la longitud de los huesos apendiculares fueron significativamente menores en comparación con el grupo control (radio, $\mathrm{p}=0,0011$; ulna, $\mathrm{p}=0,0001$; húmero, $\mathrm{p}=0,0001$; fémur, $\mathrm{p}$ $=0,0006$; tibia, $p=0,0015$ ). Por otro lado, no hubo diferencias significativas en el peso corporal de la madre y la longitud de los huesos pélvicos de las crías (isquion, íleon, p> 0,05). El estrés prenatal por restricción de movimiento altera la morfología ósea apendicular del ratón CF-1, evaluados al nacimiento.

PALABRAS CLAVE: Estrés prenatal; Ratón CF-1; Alizarina roja; Esqueleto apendicular; Morfometría; Restricción de movimiento.

\section{REFERENCES}

Ain, R.; Canham, L. N. \& Soares, M. J. Dexamethasoneinduced intrauterine growth restriction impacts the placental prolactin family, insulin-like growth factor-II and the Akt signaling pathway. J. Endocrinol., 185(2):253-63, 2005.

Barker, D. J. Intrauterine programming of adult disease. Mol. Med. Today, 1(9):418-23, 1995.

Barker, D. J. The Developmental Origins of Adult Disease. J. Am. Coll. Nutr., 23(6 Suppl.):588S-95S, 2004.

Brighton, C. T. \& McCluskey, W. P. Response of cultured bone cells to a capacitively coupled electric field: inhibition of cAMP response to parathyroid hormone. J. Orthop. Res., 6(4):567$71,1998$.

Buckigham, J. C. Glucocorticoids: exemplars of multitasking. Brit. J. Pharmacol., 147(Suppl. 1):S258-68, 2006.

Buckwalter, J. A.; Glimcher, M. J.; Cooper, R. R. \& Recke, R. Bone biology. J. Bone Joint Surg., 77:1256-75, 1995.

Buynitsky, T. \& Mostofsky D. I. Restraint stress in biobehavioral research: Recent developments. Neurosci. Biobehav. Rev., 33(7):1089-98, 2009.
Carboni, E.; Barros, V. G.; Ibba, M.; Silvagni, A.; Mura, C. \& Antonelli, M. C. Prenatal restraint stress: an in vivo microdialysis study on catecholamine release in the rat prefrontal cortex. Neuroscience, 168(1):156-66, 2010.

Chrousos, G. P. \& Gold, P. W. The concepts of stress and stress system disorders. Overview of physical and behavioral homeostasis. JAMA, 267(9):1244-52, 1992.

Cook, S. C. \& Wellman, C. L. Chronic stress alters dendritic morphology in rat medial prefrontal cortex. J. Neurobiol., 60(2):236-48, 2004.

de Kloet, E. R.; Joëls, M. \& Holsboer, F. Stress and the brain: from adaptation to disease. Nat. Rev. Neurosci., 6(6):463-75, 2005.

De Vos, P.; Saladin, R.; Auwerx, J. \& Staels, B. Induction of ob gene expression by corticosteroids is accompanied by body weight loss and reduced food intake. J. Biol. Chem., 270(27):15958-61, 1995.

Gameiro, G. H.; Gameiro, P. H.; Andrade Ada, S.; Pereira, L. F.; Arthuri, M. T.; Marcondes, F. K. \& Veiga, M. C. Nociceptionand anxiety-like behavior in rats submitted to different periods of restraint stress. Physiol. Behav., 87(4):643-9, 2006.

Hardy, R. \& Cooper, M. S. Bone loss in inflammatory disorders. J. Endocrinol., 201(3):309-20, 2009.

Harris, W. H. \& Heaney, R. P. Skeletal renewal and metabolic bone disease. N. Engl. J. Med., 280(6):193-201, 1969.

Holemans, K.; Aerts, L. \& Van Assche, F.A. Fetal growth restriction and consequences for the offspring in animal models. J. Soc. Gynecol. Investig., 10(7):392-9, 2003.

Ikeda, S.; Morishita, Y.; Tsutsumi, H.; Ito, M.; Shiraishi, A.; Arita, S.; Akahoshi, S.; Narusawa, K. \& Nakamura, T. Reductions in bone turnover; minerals and structure associated with mechanical properties of lumbar vertebra; femur in glucocorticoid-treated growing minipigs. Bone, 33:779-87, 2003.

Lavine, M. D. \& Grodzinsky, A. J. Current concepts review. Electrical stimulation of repair of bone. J. Bone Joint Surg., 69A:626-30, 1987.

Lordi, B.; Patin, V.; Protais, P.; Mellier, D. \& Caston, J. Chronic stress in pregnant rats: effects on growth rate anxiety and memory capabilities of the offspring. Int. J. Psychophysiol., 37(2):195-205, 2000.

Magariños, A. M.; Verdugo, J. M. \& McEwen, B. S. Chronic stress alters synaptic terminal structure in hippocampus. Proc. Natl. Acad. Sci. USA, 94(25):14002-8, 1997.

Mairesse, J.; Lesage, J.; Breton, C.; Bréant, B.; Hahn, T.; Darnaudéry, M.; Dickson, S.L.; Seckl, J.; Blondeau, B.; Vieau, 
D.; Maccari, S. \& Viltart, O. Maternal stress alters endocrine function of the feto-placental unit in rats. Am. J. Physiol. Endocrinol. Metab., 292(6):1526-33, 2007.

Miller, S. C.; Bowman, B. M. \& Jee, W. S. Available animal models of osteopenia - small large. Bone, 17(4 Suppl.):117S-23S, 1995.

Minagi, T.; Izumi, Y.; Chatani, F. \& Matsumoto K. Restraintinduced maternal stress and alteration of ossification in mouse fetuses. Congenit. Anom. (Kyoto), 49(3):108-12, 2009.

Myers, R. E. Maternal psychological stress and fetal asphyxia: a study in the monkey. Am. J. Obstet. Gynecol., 122(1):47-59, 1975 .

Namgung, R. \& Tsang, R. C. Bone in the pregnant mother and newborn at birth. Clin. Chim. Acta, 333(1):1-11, 2003.

Olsen, B. R.; Reginato, A. M. \& Wang, W. Bone development. Annu. Rev. Cell Dev. Biol., 16:191-220, 2000.

Orzechowski, A.; Ostaszewski, P.; Brodnicka, A.; Orzechowski, A.; Wilczak, J.; Jank, M.; Balasinska, B.; Grzelkowska, K.; Ploszaj, T.; Olczak, J. \& Mrówczyn'ska, A. Excess of glucocorticoids impairs whole-body antioxidant status in young rats relation to the effect of dexamethasone in soleus muscle and spleen. Horm. Metab. Res., 32:174-80, 2000.

Owen, D.; Andrews, M. H. \& Matthews, S. G. Maternal adversity, glucocorticoids and programming of neuroendocrine function and behaviour. Neurosci. Biobehav. Rev., 29(2):209-26, 2004.

Radley, J. J.; Rocher, A. B.; Miller, M.; Janssen, W. G.; Liston. C.; Hof, P. R.; McEwen, B. S. \& Morrison, J. H. Repeated Stress Induces Dendritic Spine Loss in the Rat Medial Prefrontal Cortex. Cereb. Cortex, 16(3):313-20, 2006.

Raiz, L. G. \& Kream, B. E. Hormonal control of skeletal growth. Ann. Rev. Physiol., 43:225-38, 1981.

Romano, T.; Wark, J. D.; Owens, J. A. \& Wlodek, M. E. Prenatal growth restriction and postnatal growth restriction followed by accelerated growth independently program reduced bone growth and strength. Bone, 45(1):132-41, 2009.

Seckl, J. R. \& Holmes, M. C. Mechanisms of disease: glucocorticoids, their placental metabolism and fetal 'programming' of adult pathophysiology. Nat. Clin. Pract. Endocrinol. Metab., 3(6):479-88, 2007.

Sharp, P. \& La Regina, M. The Laboratory Rat. Boca Raton, CRC Press, 1998. pp.33-51.

Sliwa, E.; Dobrowolski, P. \& Piersiak, T. Bone development of suckling piglets after prenatal, neonatal or perinatal treatment whit dexamethsone. J. Anim. Physiol. Anim. Nutr. (Berl.), 94(3):293-306, 2010.
Weinstein, R. S.; Wan, C.; Liu, Q.; Wang, Y.; Almeida, M.; O’Brien, C.A.; Thostenson, J.; Roberson, P. K.; Boskey, A. L.; Clemens, T. L. \& Manolagas, S. C. Endogenous glucocorticoids decrease skeletal angiogenesis, vascularity, hydration, and strength in aged mice. Aging Cell, 9(2):147-61, 2010.

Weinstock, M. The long-term behavioural consequences of prenatal stress. Neurosci. Biobehav. Rev., 32(6):1073-86, 2008.

Welberg, L. A.; Thrivikraman, K. V. \& Plotsky, P. M. Chronic maternal stress inhibits the capacity to up-regulate placental 11-hydroxysteroid dehydrogenase type 2 activity. $J$. Endocrinol., 186(3):7-12, 2005.

Correspondence to:

Pablo Lizana Arce, Ph.D

Laboratorio de Antropología Física y Anatomía Humana

Laboratorio de Técnicas Anatómicas

Instituto de Biología

Pontificia Universidad Católica de Valparaíso

Valparaíso

CHILE

Tel: 2373223

Email: pablo.lizana@ucv.cl

Received: 10-07-2012

Accepted: 08-08-2012 